AperTO - Archivio Istituzionale Open Access dell'Università di Torino

Women's and men's career interruptions in Europe: the role of social policies

This is a pre print version of the following article:

Original Citation:

Availability:

This version is available http://hdl.handle.net/2318/139365

since 2016-06-30T11:33:53Z

Terms of use:

Open Access

Anyone can freely access the full text of works made available as "Open Access". Works made available under a Creative Commons license can be used according to the terms and conditions of said license. Use of all other works requires consent of the right holder (author or publisher) if not exempted from copyright protection by the applicable law. 


\title{
WOMEN'S AND MEN'S CAREER INTERRUPTIONS IN EUROPE: THE ROLE OF SOCIAL POLICIES
}

\author{
Rosy Musumeci and Cristina Solera ${ }^{l}$
}

\begin{abstract}
How do countries differ in the type and level of women's and men's labour-market participation around parenthood? What are the models of interruptions prevalent? What is their impact on subsequent participation and wages? How does this impact depend on duration, type and "gender" of interruptions? How such impact is connected to the different social policies offered? Drawing on existing comparative datasets and offering a synthesis of the main "facts" and arguments provided so far in the literature, this paper addresses these questions by looking both at women and men and at similarities and differences within enlarged Europe. It shows that there is clearly a cost to employment discontinuities, either for unemployment or family-care, in terms of current and future participation, career opportunities, and wages, and these costs are institutionally and culturally embedded. Costs for parenthood, which are still the highest and the most "gendered", are minimal in countries that spend more on families and, within such investment, that spend more on childcare services than on cash transfers. Moreover, they are lowest in countries where rights to leaves are individual-based, where fathers have paternity leaves or a specific reserved quota in the parental leaves, where wage compensation is high throughout the period, and where length is overall relatively short.
\end{abstract}

\section{Keywords}

Labour-market interruptions, costs of parenthood, work-family reconciliation policies, EU-27

\section{Introduction}

Changes in women's behaviour with regard to fertility and labour-market participation are two of the most important processes which have reshaped the overall societal framework in the developed countries in the second half of the twentieth century and in the first decade of the twenty-first. On the one hand, together with increasing life expectancy, low birth rates have reshaped the demography both of society and of families and kin. On the other hand, the increase in women's, and particularly mothers', labour-market participation has not only changed women's life course patterns and resources; it has also changed the organisation of everyday life for families, men, and children. Men, to some extent, have indeed become more involved in what before was an exclusively domain of women, domestic and care work.

These two processes are linked in complex and ambiguous ways; they have varied across countries; and they have involved different social groups within as well as across countries, redesigning patterns of similarities and dissimilarities. Surely work and family have everywhere become more compatible. Yet, women's labour-market participation still differs importantly from that of men. This is strongly connected to the issue of the gender allocation of family responsibilities and obligations. It is women,

\footnotetext{
${ }^{1}$ This contribution is drawn on a report that Cristina Solera has prepared, on behalf of Fondazione Brodolini, for EGGE (European Network of Experts on Employment and Gender Equality Issues) financed by and prepared for the use of the European Commission (DG Justice). The authors would like to thank Mark Smith for the precious comments given during the preparation of the report, and Fondazione Brodolini for the permission to use it for this contribution.
} 
not men, who tend to adjust their supply when they get married or have children and/or when the partner's income is insufficient. Such adjustment may consist in taking a period of leave and then moving to part-time while children are young or for "ever"; in taking leave and withdrawing from the labour market; or in withdrawing before childbirth. Some women, instead, may persist with continuous full-time participation, returning soon after childbirth (Solera, 2009; Scott et al, 2009; Bettio et al, 2013). For men the main reasons for interruptions are still not family-related, having more to do with unemployment or training, although men's take up rates of leaves show signs of increase among younger generations, opening not only to new gender allocations but also to new gender and parenthood identities (Finn and Henwood, 2009; Ray et al., 2010; EIGE, 2011).

These different types of adjustment around parenthood then have different consequences on women's and men's careers in terms of subsequent participation, and in terms of class mobility and wages. As a vast literature shows, the type of adjustment and the cost of motherhood prevalent in one country or among a specific group of women varies according to a complex set of material and symbolic resources, to which women and couple have access: resources of gender definitions, human and social capital, income and time; resources furnished by the women themselves, their partners, the kinship network, or the state. Crucial in shaping cross-country differences in women's and men's employment patterns over the life course is the package of reconciliation policies offered and their orientation: that is, the extent to which they "defamilialise" caring responsibilities and child costs, and the extent to which they do so by investing more in services than in cash transfers and encouraging gender equality within families, that is, men's participation in domestic and care work (Gornick and Meyers, 2003; Lewis, 2006; Naldini and Saraceno 2011; Bettio et al, 2013).

Many studies have analysed types and consequences of labour market interruptions. Yet, they have rarely focused both on men and women or on a large set of countries. Drawing on existing comparative datasets, this piece of work offers a synthesis of the main "facts" and arguments provided so far in the literature, looking both at men and women and at all countries in enlarged Europe. More precisely, the paper is organised into three sections. Section one examines figures on women's and men's labourmarket participation in Europe, first showing comparative cross-sectional data on overall employment rates by age and presence of children, and then moving to longitudinal figures on movements over the life course, and in particular around childbirth. Section two reviews the literature on the impact of interruptions on subsequent participation and on wages after childbirth or after unemployment and it highlights how this impact varies between men and women and across countries, how it is mediated by policies and gender norms. Section three discusses the dimensions and the types of social policies that the literature has indentified as promoting or inhibiting women's labour-market attachment around motherhood, and men's contribution to care work. Then it describes how the two pillars of these policies - childcare services and leaves - are concretely designed in the different countries. The last section provides a summary of the main findings, and discusses some policy implications.

The debate on how clustering countries and gendering mainstreaming welfare typologies is a large debate, which is beyond the scope of this work. Here, in order to provide a systematic comparison and to facilitate analyses, countries are divided into six groups "simply" according to geographical area: Southern Europe, Northern Europe, Continental Europe, Eastern Europe, Baltic countries and AngloSaxon countries. These different geographical groups broadly correspond to different welfare and gender regimes, and, as we shall see, they exhibit quite different patterns of women's and men's labourmarket participation around parenthood.

\section{Mothers' and fathers' employment patterns in Europe}

\section{Different employment rates: a cross-sectional overview}

In recent decades, women's participation in the labour market has increased in most countries. Yet, in the EU-27 their levels still differ substantially. More precisely, four distinct groups of countries can be identified: countries with low employment rates (Southern EU especially Italy, Greece and Spain), countries with medium-low employment rates (those of Continental Europe, in particular France, 
Luxembourg and Belgium and those of Eastern Countries), medium-high employment rate countries (for example the UK, Germany, Austria, and the Baltic countries), countries with high employment rates (North Europe). If the 2010 Lisbon target is considered, in 2009 overall only 16 out of 27 Member States had reached the required female employment rate of over $60 \%{ }^{2}$.

The different levels and types of women's involvement in paid work are strongly connected to the issue of the gender allocation of family obligations and responsibilities. Comprehending transformations in women's involvement in the labour market therefore requires one to distinguish between parents and non-parents. Using our calculations on Eurostat, LFS, online statistics database, we can determine the following ${ }^{3}$.

In all countries except four (Slovenia, Lithuania, Latvia and Romania) women aged 25-49 with one child have employment rates lower than those of women without children: the gap is particularly wide in Eastern countries (for example, the Czech Republic: -17.1 percentage points, Hungary: -13.2pp and Slovakia: -10.5pp), whereas it is particularly narrow in Northern countries, in most of continental Europe and in Bulgaria, Romania and Portugal. Among Mediterranean countries, the employment impact of the first child is particularly wide in Malta (-20.9pp) and, among Anglo-Saxon countries, in Ireland (-13.3pp).

As regards the employment impact of the second child, in most countries the negative impact increases from the first to the second childbirth. However, while in some countries the gap between the employment rates of women with two children and those with only one child is quite wide (Malta: 12.2pp, Estonia: $-7.8 \mathrm{pp}$, Ireland: 6.7pp, Italy: 6.1pp); in others the gap is narrower and does not exceed two percentage points (Portugal, Latvia, France, Slovakia). In seven countries (Finland, Slovenia, Cyprus, Belgium, the Netherlands, Hungary and Czech Republic) women with two children have even higher employment rates than those with only one child.

The negative employment impact of motherhood is maximum for the third child: in no country is the employment impact of the third child positive (differently for the second child), and the difference between employment rates of women with three children and those of women with two children appears huge in 12 countries, where it is between $-15 \mathrm{pp}$ and $-30 \mathrm{pp}$; only in five countries is this difference below 10pp.

The gender division of paid and unpaid labour clearly emerges when the male employment rates and the impact of fatherhood are compared with this. It is women, not men, that tend to reduce their labour market participation when they have children. Men tend rather to increase it, as the positive difference in employment rates of men with children and those without signals. This suggests that a precondition to becoming a parent in a couple is that men are employed and possibly in a relatively "strong" position on the labour market, a precondition that not equally applies to women, especially among the low educated (Mencarini and Solera, 2011). Moreover, within Europe men are much less heterogeneous in their behaviours than women: the difference in employment rates between men without or with one child ranges from +3.7 in Luxembourg to +11.4 in Portugal; for women from -21 in Malta to +5.2 in Slovenia.

Employment rates by presence of children may yield a distorted representation of changes in women's and men's working behaviours, because they do not allow distinctions to be drawn among "age", "period" and "cohort" effects. The increase in women's activity rates over decades may, in fact, be the effect of different phenomena. Women may have increased both their first entry into paid work and subsequent permanence in it over family formation; they may have increased re-entries after having interrupted paid work; or they may have changed only one of these behaviours. Also the profile of women pursuing continuous careers may have changed. Women's activity rates may have increased because more women in younger cohorts have acquired the characteristics that have always favoured their attachment to the labour market (higher education, lower family burden). Alternatively, the rise in women's activity rates may derive from an increased possibility to combine paid work with marriage

${ }^{2}$ Our calculations on Eurostat, LFS, online statistics database

(http://epp.eurostat.ec.europa.eu/portal/page/portal/statistics/search database)

${ }^{3}$ Data reported in this section refer to 2009-2010, as the most updated comparative institutional dataset available from Oecd family database or Eusilc that we shall use in the second part of this contribution. 
and motherhood, and not just for some but for most women, cutting across education, class, and region. Moreover, women with more children may have lower employment rates because they stop working at the second child, or it may be that it is mainly women already out of paid work that tend to have a second or third child. Women already out of paid work may return when the family size increases due to financial necessity.

Longitudinal data help highlight when, for whom and why continuities and discontinuities occur.

\section{Continuity or discontinuity around parenthood: a longitudinal overview}

Drawing on European Community Household Panel (Eurofound, 2006, table 4, p. 57), the extent of employment continuity and interruptions over a five-year period (1995-1999) for men and women aged 15-64 in 13 EU countries can be determined. As already suggested by cross-sectional figures, there is a marked gender gap in the level of work continuity. In the period considered, one third of women against half of men were continuously employed; by contrast, $14 \%$ of men and $33 \%$ of women were not employed at all during the same period. Although, because the statistics refer to people aged 15-64 in general, what happens around parenthood and care responsibilities is not precisely indicated, the much higher proportion of women in comparison to men reporting episodes of inactivity ( $60 \%$ vs. $33 \%$ ) is certainly connected to what happens "within the family", that is, to the gender division of paid and unpaid work. It is also connected to labour market and welfare opportunities and regulations.

Spain, Italy and Greece are the countries where the proportion of inactive women is highest (over $70 \%$ vs. $45-49 \%$ in Northern countries, for example), while differences across the countries in the proportion of inactive men are minimal. Many authors have indeed described the Mediterranean countries as having an "opt in/opt out" participation pattern, rather than a universal model of discontinuous participation as in Britain, or of continuous or curtailed participation as in Scandinavia and Germany, respectively. Until recently, in Mediterranean countries a large share of women had never entered the labour market, or re-entered it after an interruption; at the same time, among those that do enter paid work, a considerable sub-set had had full-time continuous careers lasting as long as those of men (Schizzerotto et al, 1995; Bison et al, 1996; Solera, 2009).

Drawing on the same ECHP dataset, the figure below shows that everywhere a large share of working women change their participation when having their first child. However, the way in which they do so varies greatly across countries. With the exception of the Netherlands, Belgium and Ireland, the probability of women leaving the labour market after the first childbirth is higher than the probability of a change from a full-time job to a part-time one. Overall, the countries where women most adjust their participation around first childbirth are the Netherlands, followed by the UK, then Germany, Ireland, and Belgium. Types of adjustment differ among these countries: as said, in the Netherlands, and to a lesser extent in Belgium and Ireland, it is movements from full-time to part-time that prevail, whereas in the UK it is movements out of the labour market. In Germany, both types of movements affect around $20 \%$ of women each. The countries where adjustments seem overall smallest are the Mediterranean and Scandinavian ones.

These figures are in line with the results of many longitudinal comparative studies based on various data sources. By comparing UK, Germany, The Netherlands, Sweden and Japan, Kenjoh (2005), for example, shows that, in the 1980s and 1990s, the employment pattern of Swedish mothers that give birth to their first child is very different from that in the other countries. Sixty months after birth, for instance, $70 \%$ of Swedish mothers were back at work, whereas less than $50 \%$ of the mothers in each of the other countries were so. The Netherlands and the UK have experienced an increase in the employment rate of new mothers but their shares of continuous careers remain lower than in Sweden. In contrast, in Germany mothers' employment has decreased from the mid-1980s to the 1990s, while in Japan it has remained stable.

Stier and Lewin-Epestein (2001), analysing women's employment status at three points in time (after marriage but before children, when the children were in preschool age and when they were in school), reach similar conclusions. They find a dramatic shift in women's employment patterns with the arrival of children, but the shift varies across countries. Netherlands, Germany, Australia and New Zealand 
have the highest levels (over 60\%) of non-employment when mothers have preschool children, followed by Britain, Norway and Austria (above 50\%).

Figure 1. Women's transitions in Europe around first childbirth

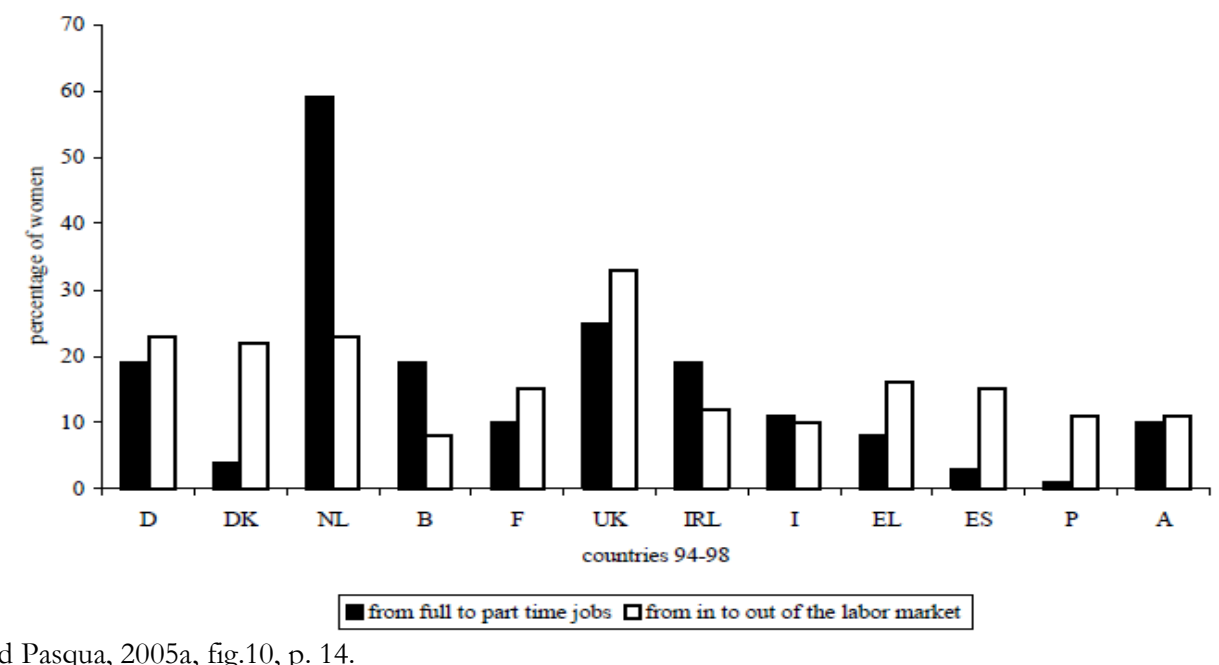

Source: Del Boca and Pasqua, 2005a, fig.10, p. 14.

\section{The impact of labour-market interruptions}

\section{Returning to work after leave}

As shown by Eurostat statistics (2009) on the basis of the Establishment Survey on Working Time and Work-Life Balance (ESWT) carried out in 2004/2005, in EU-21 44\% of the managers from establishments with employees on parental leave stated that the majority of their female employees resumed work afterwards, working the same number of hours as before; $34 \%$ of the enterprises stated that the majority of mothers asked for reduced working hours (from full-time to part-time, or a further reduction when already working part-time); and only 10\% reported that the majority of mothers did not resume work (figure 2). Yet, substantial differences exist among the 21 European countries. In the majority of countries the most frequently observed type of behaviour is the resumption of work with the same number of hours as before, followed by the reduction of working hours. By contrast, in a second group of countries (Germany, the Netherlands, Austria, Sweden and the UK) the most frequent behaviour is working at reduced hours, followed by the resumption of work with the same number of hours as before. Especially Germany and Austria, countries that might be considered to have a "conservative welfare regime", show a very pronounced concentration of answers in relation to the resumption of work at reduced hours. Finally, in the Czech Republic, Hungary, and Poland, resuming work to the same extent as before parental leave is also mentioned most often, but it is followed by total exit of mothers from the company, and presumably often from the labour market as a whole. Working reduced hours is least common for these three countries (figure 2).

The impact of a leave on maternal employment is ambiguous (Klerman and Leibowitz, 1997; Waldfogel et al., 1999; Pronzato, 2007). On the one hand, it guarantees return to the previous job so that the woman does not lose her specific human capital; on the other, it may withdraw women from the labour market for long periods, with negative implications for their future employability, wages, and career. For example, Waldfogel et al. (1999), on comparing the United States, the UK, and Japan, find evidence of a positive effect of the leave on women's job retention. Ruhm (1998), on comparing employment rates and wages among women and men in different European countries, shows that maternity leave availability is associated with an increase in women's employment but a reduction in their relative wages. Klerman and Leibowitz (1997), using US census data, find empirical evidence for the association between statutory parental leave and longer work-breaks taken by women protected by these laws. 
Pronzato (2007) suggests that the right to long and paid leave gives mothers the opportunity to remain at home with the child at a lower cost, and that lengthy statutory leaves are associated with being more likely to be at work in the period following the leave. In contrast, when parental leave compensation is flat-rate, it may inhibit participation in the long run, especially attracting low-qualified women, whose wages, in comparison with partners, are generally much lower. For example, in France, the parental leave system has been shown to have had a negative effect on labour-market participation by mothers of two children, especially the unskilled, less likely to resume work after parental leave (Afsa, 1999; Piketty, 2003). In the Nordic countries, work resumption following leave seems much easier and it is common among both highly and poorly educated women. The gap according to level of education in work-family combinations is much wider in countries such as Italy and Spain, with poor universal reconciliation policies and still quite traditional gender norms (Solera and Bettio, 2013).

Figure 2. Women returning to work after parental leave (\%)

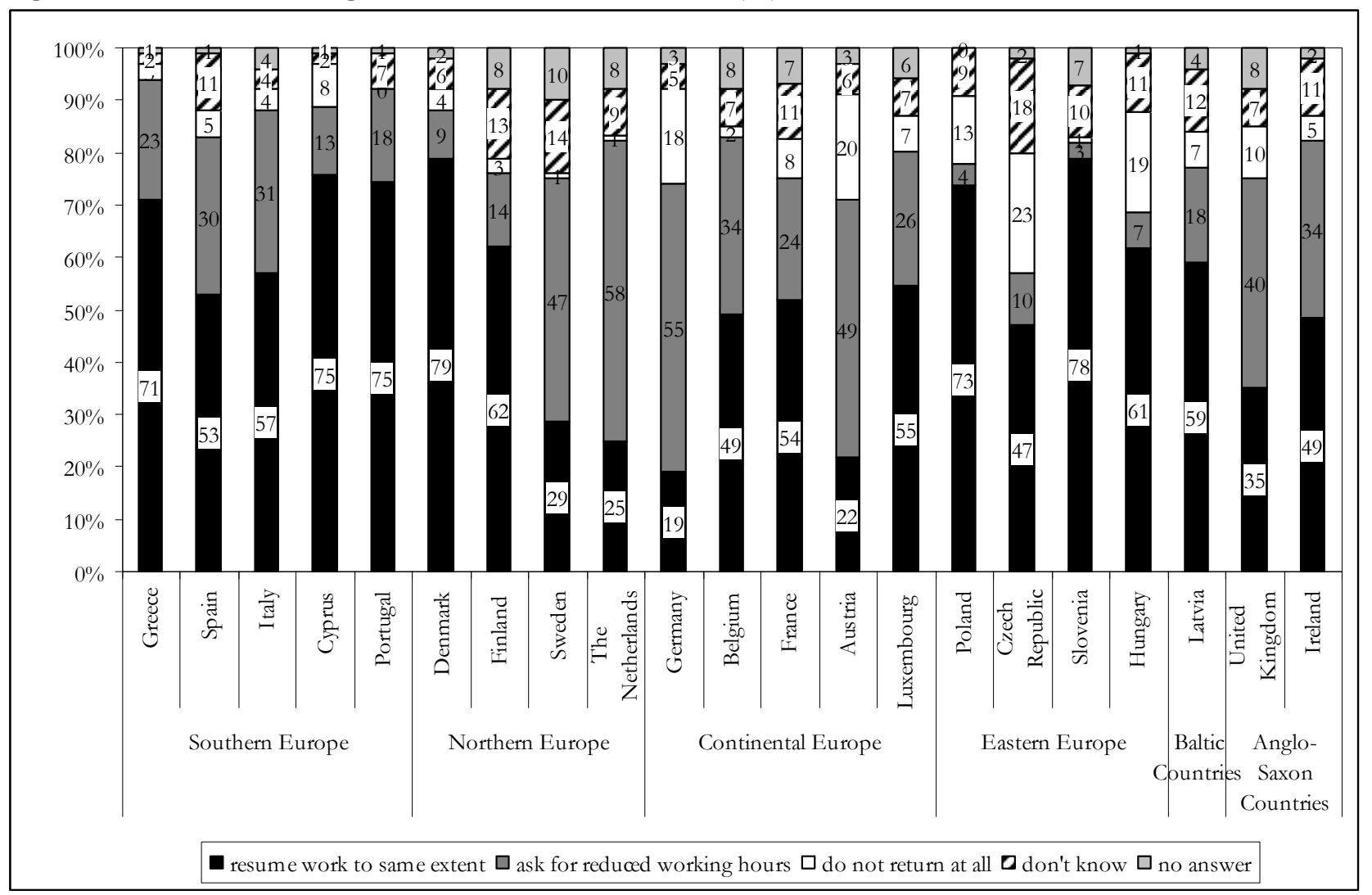

Source: ESWT Establishment Survey on Working Time and Working Life Balance 2003-2004 in Eurostat, 2009

Notes: Action taken by the majority of women as reported by enterprise managements - Base: Establishments with female employees on parental leave in the past three years (management interviews).

Some authors have tried to calculate the "optimal" amount of leave, that is, the set point of duration of leaves that maximises their positive effect on participation, both on rates and working hours. Combining both maternity and parental leave, they fix it at 28 weeks for the age group between 25 and 34. The increased participation at this point is more than $2.5 \%$. The optimal length is slightly smaller, at about six months, for the 15 to 64 age group and results in an increase in participation of $1.8 \%$ (Akgunduz and Plantenga, 2011). If only paid leave is included, the optimal length becomes shorter, around 20 weeks (Ruhm, 1998; Jaumotte, 2003). Parental leaves can have also an effect on working hours if without the possibility to take time off mothers would prefer shorter working hours to combine family and work responsibilities. Indeed, evidence shows that an increase in leave duration from 13 to 30 weeks results in a 3\% increase in weekly hours worked. By contrast, leave can have a negative impact on wages and career opportunities, especially if they extend beyond 20 weeks. A paid leave of about 20 weeks, including both maternity and parental leave, seems the optimal length: because it minimises the negative effects on high skill wages and occupational segregation, while providing the 
bulk of the participation benefits (Akgunduz and Plantenga, 2011). The next section discusses more extensively the consequences for women of taking time off for family-care on wages and career opportunities.

\section{Occupational Status and wages after a break}

Long leaves with job-protection make women more likely to return to work after childbirth. Long leaves also give women and men the opportunity to spend more time at home with their children. However the longer the time that women spend out of paid work, the more they pay a price in terms of future careers. After childbirth, many women experience downward occupational mobility. Even if a woman remains employed and takes the minimum length of leave, she may end up in an occupation that is inferior to the one held before the birth in terms of quality, payment and responsibility.

This occupational downgrading stems from the more constrained choices mothers face if they seek jobs with shorter or flexible working hours during the child-rearing years and/or because employers may be reluctant to hire mothers for high profile positions since they believe that their family role may absorb most of their energy and interfere with their productivity (Del Boca and Pasqua, 2005b).

Even in Sweden women's career prospects are better if they return to paid work sooner rather than later (Aisenbrey et al., 2008). For Germany, career interruptions reduce the wage rates of both men and women (Beblo and Wolf, 2002). However, women have a specific wage penalty, connected to motherhood, even when they do not withdraw from paid work but "simply" take maternity leave.

In Germany the size of the wage penalty due to maternal leave incurred by working mothers stands at $10 \%$ to $14 \%$ for a one-year maternal leave in the year following the return to work. Other, nonmaternal types of interruptions resulted in a somewhat lower penalty (Buligescu et al., 2008). In line with these figures, Ejrnaes and Kunze (2004) report a range of penalties for one-year leaves from 5\% to $15 \%$ depending mainly on the new mother's qualification. Maternal leave penalty is also sensitive to the duration of the leave, but only temporarily so, since five years after re-entry the maternal wage rate seems to have caught up (Buligescu et al., 2008). This suggests that crucial in order to reduce the cost of motherhood is the limitation of the time out. On the one hand, this limitation makes it possible to recoup the deterioration of human capital during maternal leave in the period following the return to work; on the other hand it avoids the negative signal effect associated with women taking long leaves and/or working part-time.

Crucial in shaping cross-country differences in the size of wage penalty associated to motherhood is the package of reconciliation policies offered. For example, Misra et al. (2007) examine the consequences of welfare-state strategies on women's economic outcomes in ten countries. These strategies are divided as follows: the primary caregiver strategy, focused on valuing women's care work represented by Germany, Netherlands, Luxembourg, Austria: the primary earner strategy, focused on encouraging women's employment represented by Canada and US; the choice strategy, which provides support for women's employment or care giving for young children represented by Belgium and France; and, finally, the earner-carer strategy, focused on helping men and women balance both care and employment and represented by Sweden. Misra et al. find that motherhood is associated with the least negative effects on employment and earnings in the countries with the earner-carer strategy, for both married and single mothers. Also in the choice countries the cost of motherhood is relatively low: French mothers do not face significant wage penalties, while Belgian married mothers face some wage penalty, but single mothers are actually less likely to live in poverty than single childless women. Evidently, programmes targeted on helping working families with children have helped equalize the situation for mothers. In contrast, the primary caregiver strategy is associated with the greatest gender gaps in employment and wages, and the greatest cost of motherhood. The primary earner strategy appears to have mixed results because, while full-time employment gaps and wage penalties faced by mothers are low in these countries, poverty rates remain high for mothers, particularly for single mothers.

Similar clusters of countries are found by Stier and Lewin-Epstein (2001). A reduction of wages due to work separation is apparent in all welfare regimes. However, where public support for work-family 
reconciliation is high, such as in Scandinavian countries, employment interruptions are fewer and shorter, so that the wage penalty of motherhood is minimal.

Using harmonised longitudinal data, Gangl and Ziefle (2009) trace career prospects after motherhood for five cohorts of American, British, and West German women around the 1960s and they confirm that the wage costs of motherhood differ across countries. They find that, although public support for the cost, direct and indirect, of children in the US is the lowest, it is in Germany that the wage cost of motherhood is highest. Moreover, unlike in Britain and the US, in Germany there is no evidence of any negative effect of employer change at return to the labour market, nor any marked negative effects of work interruptions. The wage penalty in Germany is "residual". The higher penalty associated with child-related work interruptions in Britain compared with the US, and even more so the excessive residual wage penalty found for German mothers, suggest that mothers are more strongly penalized as a group in Europe than in the US labour market.

The explanation given is that time out of the labour market is costly to American women because human capital accumulation is such an important determinant of wages in the US, given that returns to experience are clearly well above those for women in Europe, especially in Germany. Moreover, women's behaviour in the American labour market is much more market oriented than in Britain or Germany. American mothers take much less time off for childcare, and they are much less likely to enter part-time jobs, typically female jobs, or low-prestige occupations in response to childbirth than are mothers in Britain and Germany. In Germany, public subsidies are higher, but they are mainly furnished through generous pro-fertility cash transfers and long leaves, rather than through childcare services, which encourage women to stay home more than to combine family with work responsibilities. Moreover, German employers expect that women will take long leaves, so that they are successful in passing on the economic costs of family policy mandates to mothers.

\section{When men interrupt}

Unlike women, men rarely interrupt to take leaves or to withdraw from the labour market in order to dedicate themselves to full-time family care. Rather, men's typical type of interruption is for unemployment. This implies a non accumulation and a deterioration of human capital, and a signal to employers, leading to a negative impact on future participation and wages. Yet, the size and duration of such impact vary, between men and women, between different types of interruptions, and across countries.

Gregg and Tominey (2005) use the National Child Development Survey in the UK and observed how for men the experience of youth unemployment affected wages, and whether there was a subsequent recovery up to twenty years later. They find a wage scar in the magnitude of $13-21 \%$ at age 42 , for a year of youth unemployment, even after controlling for education, region, family wealth and individual characteristics. However, the penalty was lower, at $9-11 \%$, if men avoided repeat incidence of unemployment. For women wage penalty resulted lower (Gregg and Tominey, 2003). Men carrying the worst unemployment histories from their youth labour market experience will experience a 30\% penalty ( $£ 4.00$ per hour), compared to men with no experience of youth unemployment. The wage gap is large for men whether the wage is measured at age 23, 33 and 42. For women the penalty is approximately $f 2.00$ per hour at age 42 and is consistently slightly lower compared to women with no youth unemployment than for men. For men with 5 to 12 months unemployment wages are 11-16\% lower, while $6-9 \%$ for women. The log wage penalty of experiencing some youth unemployment declines once controlling for family and individual specific characteristics, but only marginally. Generally men, whose male breadwinner and work-centred role is considered normal, pay a higher penalty for unemployment than women who are normally the main caregivers, and are assumed to have a weaker attachment to paid work

Training is the only type of interruptions that generates positive wage effects for both sexes. With data on West Germany, Beblo and Wolf (2002) show that the wage penalty of discontinuous employment biographies are very different, in sign and size, according to gender and to type of interruption. Men's wages are mainly negatively affected by unemployment and inactivity episodes, 
whereas those of women by parental leave and additional time at home, even if taking place several years go. Training breaks increase future wages for both women and men. Among women, those experiencing unemployment have lower wage cuts than those staying out of the labour market. This implies that female wages are primarily determined by the women's attachment to the labour market. This might be the result of two mechanisms. First, unemployed women are more likely to receive some training that women out of the labour market, so that their skill obsolescence is lower. Second, parents that take employment breaks around childbirth, especially if long, tend to be stigmatised as less motivated and hence less productive (Albrecht et al., 1999).

Given prevalent gender ideologies and practices, this stigmatisation seems to be particularly high when the number of men who take leave or desire to work part-time, is low. In many countries interviews to them reveal a preservation of breadwinner masculinities, connected to devaluation of men's caregiving and to sanctions against men in new roles (Holter, 2007). In addition to institutions, cultural and social norms are thus also important in shaping frequencies and consequences of men and women's labour market interruptions around family formation.

\section{The role of social policies}

\section{Identifying policies affecting parents' labour-market interruptions}

Differences across countries in frequencies and consequences of men and women's labour market interruptions have many causes. Countries differ in the supply profile of working women, in labour demand, and in their cultural and institutional settings. The latter play a crucial role. The concept of the de-familialisation of care responsibilities and the way this goes hand in hand with more gender equality in the share of care within the family is crucial. De-familialisation refers to the degree to which the family is released from its caring and welfare responsibilities, via either welfare state provision or market provision. This affects women's labour-market participation in three ways. Firstly, on the supply side, the provision of extra-family care services and extra time for care change the relative advantage of paid work versus unpaid work and enable women to combine paid work with children. They thus favour continuous careers. Secondly, on the demand side, the externalisation of family goods and services contributes to development of the service sector, which mainly attracts female labour. Thirdly, institutions also define "normality models" for the entire population, of for specific subgroups within it, making some choices more or less possible but also more or less desirable and socially legitimated.

The issue of care, how it is distributed not only between the family, the market and the state, but also between men and women is crucial. Not all care can be commodified and externalised, so that scant attention to how care is valued and shared, risks reinforcing gender inequalities or producing new ones. In order to reach gender equality, policies should not focus only on the work/welfare relationship and on the women's participation to paid work; they should also address the distribution of time and men's participation in unpaid domestic and care work (Lewis 2002, 2006; Fraser 1994; Leitner 2003; Mc Laughlin \& Glendinning 1994; Saraceno 2000; Saraceno and Keck 2010; Naldini and Saraceno 2011).

As Bettio and Plantenga (2004), Lewis (2006), and Gornick and Meyers (2003) point out, policies intended to "defamilialise" caring responsibilities and child costs, while at the same time supporting maternal employment, should affect three dimensions: services, time, and money. In turn, they should comprise childcare services, maternal, parental and paternity leave policies, income transfers to child families, and working time regulations. The effect of these measures on women's employment patterns over family formation depends on the degree and type of "de-familialisation" or "familialism" that they actually promote or produce; on how the three pillars of income, service and time are individually designed (eligibility criteria, duration, costs and level of income support, availability and quality etc.); and on whether and how they support work-family reconciliation. Important too is the extent to which men are encouraged to conciliate by sharing time for domestic and care work, and the degree of universalism: that is, how income and/or labour-market history and position act to define eligibility and levels of support. Finally, it is also important whether all pillars are in place and how they are combined with each other. What indeed really matters are not single policies but packages of policies. The high 
attachment to the labour market of Nordic women is the joint outcome of a good public childcare system and job-protected, well-paid and relatively short maternity leaves, in combination with paternity and parental leaves, with universal cash benefits and with a higher participation of men to unpaid work compared to other countries. In addition, low wage inequalities and "employee-friendly" flexibility restricted to normal weekly working hours facilitate the conciliation of parenthood and employment.

The following describes how the two pillars of these policies - childcare services and leave schemes - are configured in the different countries in the $\mathrm{EU}^{4}$. A brief overview of how countries differ in their overall public investments in support to families preceeds this.

As figure 3 shows, in 2009 Mediterranean countries record the lowest public spending for families and children in Europe (less than 1.8\%). At the opposite extreme, Northern, Continental and AngloSaxon countries present higher percentages of public spending on the family with the former characterized by the highest percentage of public spending on services. Eastern Europe exhibits a medium level of public spending in this category, but percentage-wise, family benefits in cash were higher. Hence, there seems to be a correspondence between levels and type of spending and levels and type of women's labour-market participation. Countries with higher incidences of continuous careers are those that spend more on families and, within such investment, they are those that spend more on childcare services than on cash transfers.

Figure 3. Public spending on family benefits in cash, services and tax measures, in per cent of GDP, 2009

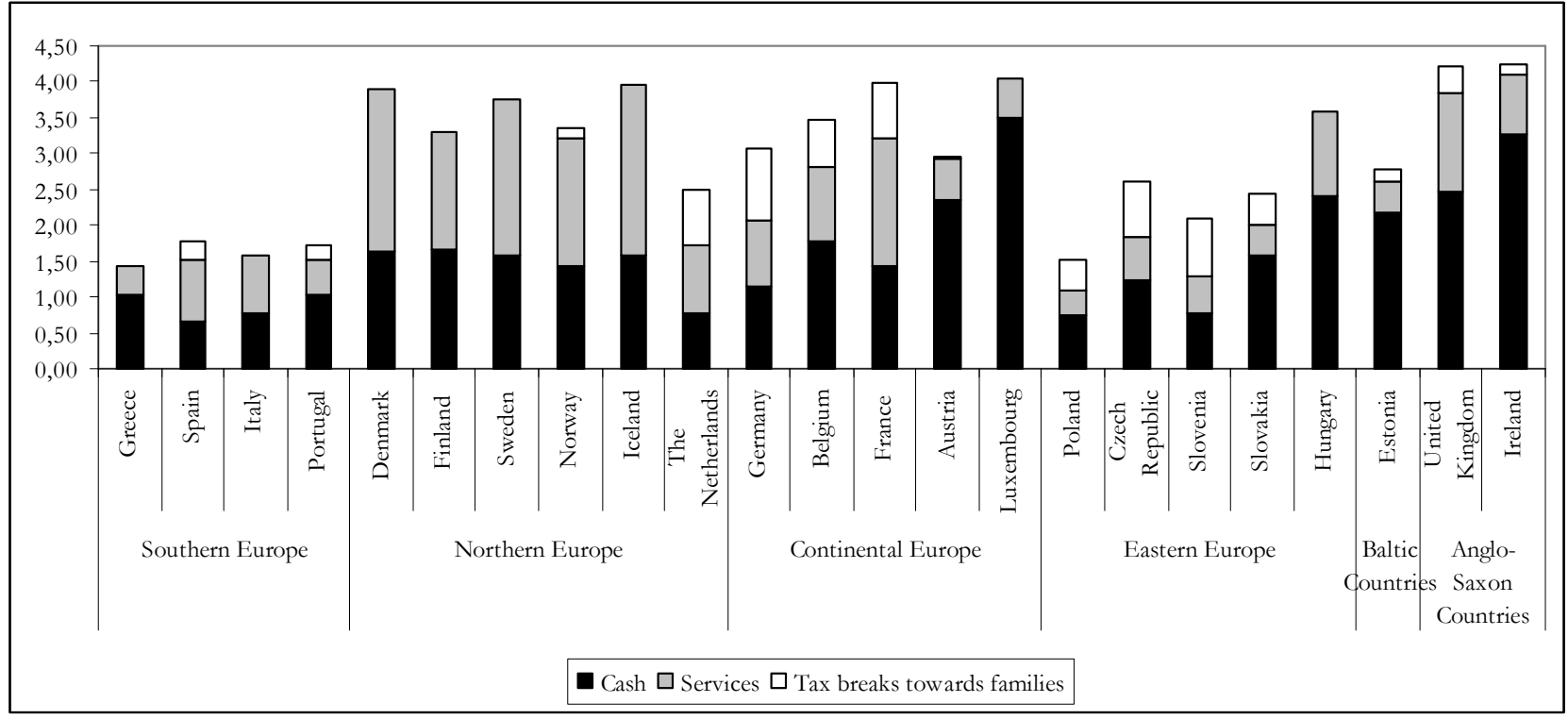

Source: Social Expenditure Database (www.oecd.org/els/social/expenditure), November 2012

Notes:

- Public support accounted here only concerns public support that is exclusively for families (e.g. child payments and allowances, parental leave benefits and childcare support). Spending recorded in other social policy areas as health and housing support). Spending recorded in other social policy areas as health and housing support also assists families, but not exclusively, and is not included here.

- Data missing for Turkey. Data on tax breaks towards families is not available for Greece and Hungary.

1 The data for Israel are supplied by and under the responsibility of the relevant Israeli authorities. The use of such data by the OECD is without prejudice to the status of the Golan Heights, East Jerusalem and Israeli settlements in the West Bank under the terms of international law.

\section{Childcare services}

There is broad consensus that childcare services are of great importance in supporting the employment of mothers, more generally, the reconciliation between parenthood and employment. Indeed there is a great deal of evidence that furnishing child-care services which are cheap, widely available, with long

\footnotetext{
${ }^{4}$ For reasons of space, the different flexible working arrangements, such as part-time, the possibility to vary (usually and occasionally) the start or the end of the working day or the possibility to organise one's working time by taking days off for family reasons, are not described. For a review of them across Europe see Plantenga and Remery, 2009a.
} 
hours coverage, and of good quality, increases women's labour supply and the possibility of working when the child is young (Fagnani, 1996; Gustafsson, 1994; Gornick and Meyers, 2003; Del Boca and Wetzels, 2007). For example, a study by Uunk et al. (2005) on the impact of young children on women's' labour supply find that one-third of the observed country differences in the 'child effect' are due to differences in public childcare. This is because childcare subsidies reduce the probability of exiting the labour market when children are young and potentially eliminate the monetary cost of motherhood and fatherhood. It also occurs because support for childcare time and costs increase the labour supply of low-earning potential mothers (Gornick et al, 1997). Some studies also argue that where defamilisation via public childcare services is higher, men are more participative in the division of care left to the family (Esping-Andersen, 2009).

The Barcelona Summit in 2002 established that by 2010, EU member states should provide at least 33 places for every 100 children aged under 3, and 90 for every 100 children aged over 3 . Investments in childcare services are crucial not only to improve women's labour-market participation, and gender equality, but also child well being. For children, early education services may not entirely compensate for the lack of material resources, but they may partially offset the consequences of this scarcity on the development of cognitive skills, thereby breaking the vicious circle of the intergenerational reproduction of poverty and inequality (Esping-Andersen, 2009). Moreover, child economic poverty is lower in dual-earner families or in lone-parent working families. In a context of increasing uncertainty in the labour market, also for male breadwinners, and in the family, with high rates of divorce, women's attachment to paid work is indeed an insurance against the risk of falling into poverty (Solera and Negri 2008).

Figure 4 shows that nine Member States (Denmark, Sweden, Netherlands, France, Spain, Portugal, United Kingdom Luxembourg and Belgium) have already met the Barcelona target, with Slovenia close behind. At the lower end of the ranking, Poland, the Czech Republic, Slovakia and Romania have a percentage of maximum 5\%. The difference between the lowest and the highest ranking country is 70 percentage points, with Denmark having about $73 \%$ share of children cared for in formal arrangements, whereas Poland only score about $2 \%$.

In almost all countries, the younger the child, the more likely it is that he/she is cared for at home, especially by the parents, followed by other groups, such as grandparents and/or other relatives. Newborn children spend on average 11 months with parents, while they are on maternity or parental leave (for example, in Sweden, hardly any children below the age of 1 year are in public childcare since they are at home with a parent on parental leave) and towards the end of that period many children gradually start day-care with a few hours a day (Plantenga and Remery, 2009b).

Most formal childcare services are used for 30 hours or more in countries such as Denmark, Iceland, Portugal, Slovenia, Finland, Latvia, Greece, Hungary, Slovakia, Lithuania and Poland. In other countries, part-time use of childcare services is much more common. In Germany or in the Netherlands, childcare services are provided on a full-time basis, but the use of the facility is limited to few days per week, reflecting the high level of part-time employment in the Netherlands. Hence in the Netherlands only $4 \%$ of the children are taken care of in formal arrangements for more than 30 hours per week. In the United Kingdom too, employed mothers typically work part-time, and the part-time use of childcare services is high (Plantenga and Remery, 2009b).

Also how childcare costs are divided between state, parents and employers affects the use of outof-home services, and, in turn, maternal employment. Parental contributions vary. In some countries parents have a relatively low share in the costs (less than $25 \%$ ) (Sweden, where parents seem to pay the smallest part, $8 \%$, Hungary 10-15\%, Estonia $12 \%$, Austria $15 \%$, Finland $15 \%$, Belgium $17 \%$, Germany and the Netherlands both $19 \%$ and Iceland about $25 \%$ ). In another group of countries, the parental contribution is about $40 \%$ : for example in Portugal (38\%) and Liechtenstein (40\%). Finally, in two countries parents pay a relatively high share: the United Kingdom (75\%) and Poland (80\%) (Plantenga and Remery, 2009b). 
Figure 4. Proportion of children under 3 years old in formal and other types of childcare, 2009

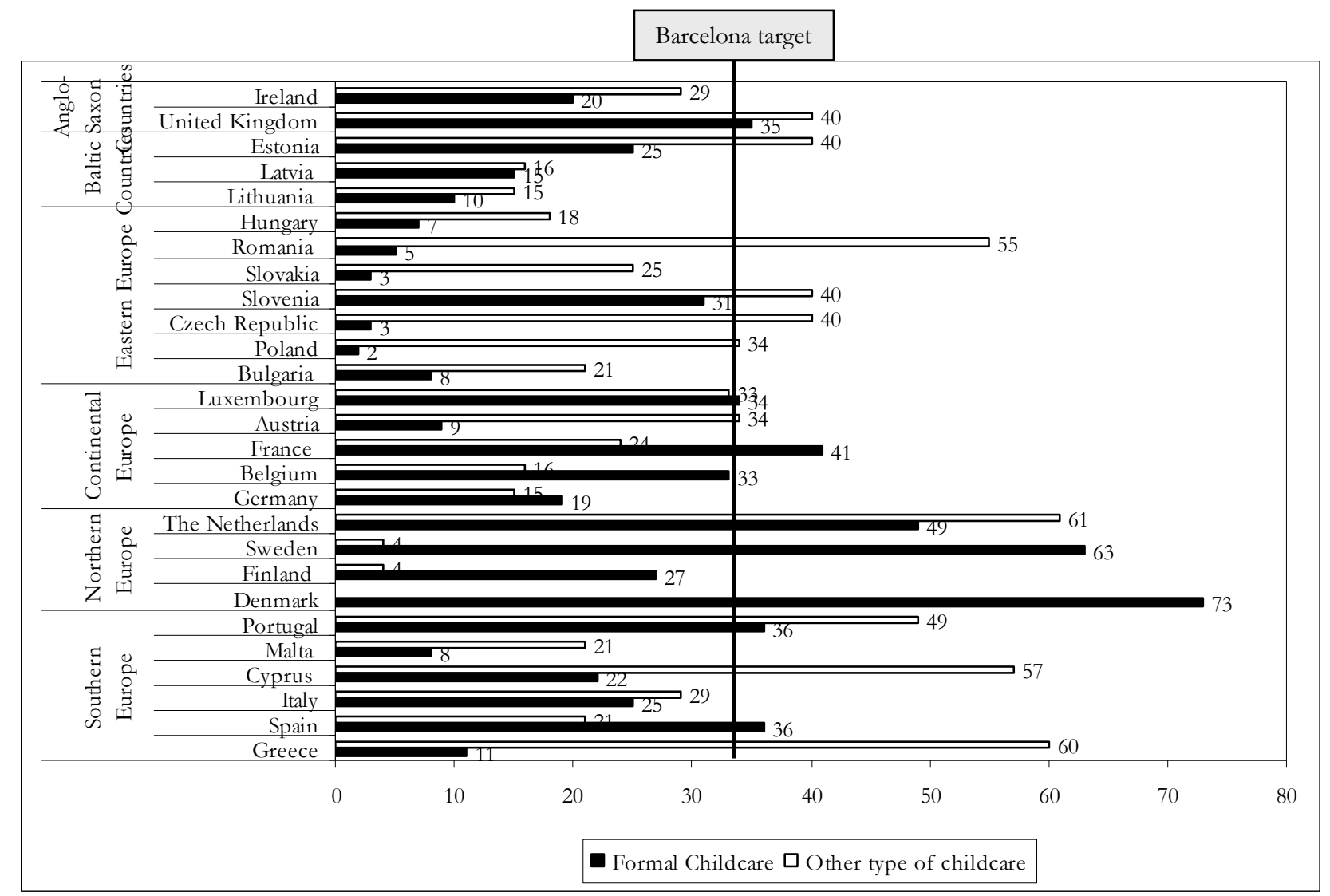

Source: Eurostat, EU-SILC 2009 in EIGE (2011) page 14

Notes: Percentage of children in formal and other types of childcare out of the total number of children in the same age group. Data on "other types of childcare" for Denmark is not available.

\section{Leaves schemes for mothers and fathers}

The relationship between maternal employment and leave policies is more debated than that between maternal employment and child-care subsidies. Leave provisions are important because they provide basic income support for new mothers and fathers and prevent them from exiting employment following childbirth. Evidence shows that access to leave schemes facilitates continuous employment and, in the short run, reduces the wage penalty associated with motherhood. However, whilst child-care services enable mothers to spend more time working, leave enables working mothers and fathers to spend more time at home, thereby limiting career-enhancing opportunities. Indeed, leave is associated with an increase in women's employment in the short run, but with a reduction in the relative wages and in the quality of their jobs in the long one. A vicious circle seems to operate: allowing a woman to take leave of absence, especially if for long time, further exacerbates unequal treatment in the labour market, causing human capital depreciation but also emitting negative signals to employers (De Henau et al., 2007).

These effects obviously depend on the characteristics of maternity and parental leave programmes. As widely acknowledged, of great importance are the levels of wage compensation and job protection, the duration of both paid and unpaid leave, and the degree of flexibility in its use -on a part-time or full-time basis, all at once or spread over a number of years, also when the child is older, plus the extent to which and how fathers are entitled to take leave. As Smith points out (2004), the most decisive factor in fathers' time-off-work behaviour is the level of replacement income. It is also important for leave to be granted as an individual right not transferable between partners. Indeed, there is a positive correlation between parental leave legislation and the share of fathers in the overall period of leave taken by 
parents (De Henau et al., 2007). Similarly, father-friendly legislation is correlated with both absolute and relative levels of fathers' time spent caring for children (Smith and Williams, 2007). Employed fathers who spend most time with their children also experience the most favourable labour market outcomes: earn more per hour and work fewer hours per week (Smith Koslowski, 2011). Their time with children has a positive impact on women's labour market participation, too. The design of parental leaves matters. By using EU SILC, Reich (2011) shows that the father's exclusive entitlement to use parental leave at a high replacement rate is positive and significant in all models for mother's employment and wages. In general, policies that "familialise" men - that is, which allow fathers to spend time caring for children with a low wage penalty - indirectly support maternal employment because they may favour a redistribution of caring responsibilities and may reduce the negative signalling effect on the part of women to employers (European Childcare Network, 1994; De Henau et al, 2007; Gornick and Meyers, 2003).

The Oecd and Missoc databases allow to reconstruct the leave systems of the different countries in the EU. In 2011/2012, most countries have a statutory and designated Maternity leave entitlement whose length in all EU-27 Member States is longer than that set forth by the European Commission (equal to or above fourteen weeks, the minimum period required by EU legislation ${ }^{5}$ ), except, among Continental countries, for Germany (14 weeks) among Northern countries, for Iceland (13 weeks) and Norway (9 weeks). The longest leave is in Eastern countries, Slovakia (34 weeks) and Czech Republic (28 weeks), Hungary ( 24 weeks) but these countries also have lower replacement rates of earnings in comparison with the other countries (for example 55\% in Slovakia, 70\% in Hungary, 75\% in Czech Republic). This is also true of Ireland, where maternity leave is very long ( 42 weeks), the replacement rate of earnings is low ${ }^{6}$.

Paternity leave refers to a period immediately after the birth that is only available to fathers and usually paid on the same basis as maternity leave but is much shorter: it varies from a few days to four weeks (in Lithuania) across the European countries in which it exists. All the Northern and Baltic countries offer statutory paternity leave, while it is not offered by three of the five Southern countries (Italy, Cyprus, Malta) and three of the six Eastern countries (Bulgaria, the Czech Republic, Slovakia). Among Continental countries Germany and Austria $^{7}$ do not offer paternity leave; nor does it exist in Ireland. In general, Maternity and Paternity leaves are far from being equal in length in all countries. The majority of Eastern countries combine long maternity leave with no paternity leave. The same applies to Ireland (26 weeks of maternity leave $v s$ no paternity leave) and, among Mediterranean countries, to Italy, the Southern country with the longest maternity leave (20 weeks) and no paternity leave $^{8}$ (while it exists in Spain, where it is 15 days, in Portugal and Greece). Paternity leave is relatively longer in Northern countries: for example, in Finland it lasts 18 days, Denmark and Norway 2 weeks, Sweden 10 days. In Iceland, maternity and paternity leave are identical: 13 weeks and with a high level of payment $(80 \%$ of earnings).

Parental leave differs across countries in both length and type of entitlement. Length ranges from the minimum period required by the European Commission directive of 3 months per parent (Belgium, Cyprus, Greece, Malta, Ireland, the Netherlands, Portugal, and the UK) to until the child's third birthday (Czech Republic, Germany, Spain, France, Hungary, Estonia, Latvia, Lithuania, Poland, and

\footnotetext{
5 This length is believed to be the necessary minimum in medical terms to allow mothers fully to recover after childbirth.

${ }^{6}$ Countries also diverge in terms of the body responsible for the payment of maternity leave. In most countries, maternity leave is funded by social security contributions, mostly health insurance (in the Netherlands, maternity leaves are paid as unemployment benefits). However, in some countries tax revenue is use to finance the maternity leave system. This is, for example, the case in Ireland, Portugal, Slovenia and Spain. Finally, it may be the employer who is responsible for earnings replacement during the period of maternity leave. This is a feature of the Danish system (and in part of Germany). Employers' intervention in maternity leave payment may therefore be regarded as a tax on female labour.

${ }^{7}$ In Austria there is no statutory entitlement to paternity leave, though collective agreements may provide a few days off for fathers immediately after the birth of a child, during which time fathers receive full earnings replacement.

${ }^{8}$ In Italy paternity leave has just been introduced, starting from 1 January 2013. Yet it is very short, it is compulsory for one day and optional for two days until the child is 5 months old.
} 
Slovakia). The right to leave is individual ${ }^{9}$ in the Anglo-Saxon countries, in all Mediterranean countries, and in some Continental countries (as Belgium, France and Luxembourg). In all the Baltic countries, in the majority of Eastern countries, and in some Continental countries (such as Germany) the right to leave is family-based. As regards payment, Anglo-Saxon countries do not grant any replacement income during the leave. Among the Mediterranean countries only Italy and Portugal provide some element of payment, while all the Northern ${ }^{10}$ and Continental countries do so.

Parental leave differs among European countries also in its flexibility which includes the possibility for parents to choose to use all or part of their leave until their child reaches a certain age; to take leave in one continuous or several shorter blocks; to take leave on a full-time or part-time basis; or to take additional leave in the case of multiple births. Some countries emphasise that parents should be able to care for their children themselves in their first years of life, so that leave should be taken immediately following childbirth: this is the case of Spain, of almost all Eastern countries (Czech Republic, Slovakia, Hungary, Romania), Baltic countries (Estonia, Lithuania), Denmark and Finland among the Northern countries, and France and Austria among the Continental countries. In other countries (Sweden, the Netherlands, Germany, Italy, Malta, Ireland, Latvia), the age limit is much higher, up to 8 years. Finally, most leaves are fractionable but to different degrees.

Countries also differ in fathers' use of parental leaves. As said, men's take up rates are higher where parental leaves are paid with a high replacement and rights are individual and not transferable between partners. On the other hand, men's take up rates are lower if gender norms consider women as the main and "natural" caregivers, so that men flouting such norms face high penalties in their career advancements.

\section{Gender norms and the gender division of unpaid work}

Social norms matter in shaping women's and men's work transitions around family formation, those prevailing in the society and those assumed or promoted by the type of social policies implemented. Many studies suggest that labour-market participation by women tends to be higher and less interrupted after the childbirth and during the child-rearing period in countries with not only family friendly policies but also a modernised and egalitarian gender cultural and social norms.

Our research using the Online OECD Family database ${ }^{11}$ shows the percentage of time devoted to care work by number of children under school age (7) for women and men aged 25-44 and groups of countries. Women devote more time to care work in all cases, both when they have children but also when they do not have children; but the gender gap is wider in the presence of children, especially when women have two or more. For families with two or more children, women devote more time to care work than men in the UK $(+13.9 \%)$, Finland $(+12.9 \%)$, Germany $(+12.8 \%)$ and Italy $(+12.5 \%)$. The gender gap is smaller in Sweden $(8.2 \%)$, France $(8.3 \%)$, and Latvia $(+8.2 \%)$. In Eastern countries, high participation of women in market work seems not to be accompanied by high participation of men in family work. Gender equality and the full employment of women were official aims of the state to be achieved with the help of state services. However, in policy discourse and practice, only weak emphasis was placed on the division of care between men and women (fathers, for example, had no right to any family- or child-related leaves or benefits) (Karu and Pall, 2009).

As argued by efficiency and bargaining theories, the gender division of domestic and care responsibilities is affected by own and partner's attitudes, earning power, and time availability. Gender gaps in domestic work tend to decrease for highly educated couples, while gender gaps in childcare

\footnotetext{
${ }^{9}$ In the first case, each parent is entitled to a period of leave that is not transferable to the spouse; if a parent does not take the leave to which he/she is entitled, it is lost for the family. In the second case, parental leave is a family right and can be shared by both parents more or less freely, depending on the country.

${ }_{10}$ More precisely, in the Netherlands parents taking parental leave are entitled to a tax reduction.

11 wmw.oecd.org/els/social/family/database; Year: 1999: France; 2000: Estonia, Finland, Hungary; 2001: Norway, Slovenia, Sweden, United Kingdom; 2002: Germany; 2003: Italy, Latvia, Lithuania, Spain; 2004: Poland; 2006: Belgium. Care work includes all episodes of care work declared as the primary or secondary activity. It also includes the time spent on caring for household members or on informally helping other households.
} 
increase in the majority of countries. The increase in the gender gap in childcare is due to the more than proportional increase with level of education of childcare by women compared to men. This is in line with the literature that documents evidence of a positive relation between time spent in child care and education (Francavilla et al., 2009).

The gender division of domestic and care responsibilities is also affected by macro settings, by welfare state, kinship solidarity, and the regulation and functioning of the labour market. For example, in a comparative study on welfare regime differences in the domestic division of labour, Geist (2005) demonstrates that the equal sharing of housework is rare in conservative countries, whilst it is more widespread in Scandinavian and liberal countries, regardless of individual relative resources, time availability, and gender ideology. This may mirror both cultural and institutional dimensions. In societies where traditional gender roles are institutionalised by being promoted and legitimated in social policies, and where, in turn, attitudes are less egalitarian, it is more difficult to find not only women but above all men supportive of women's employment and of a more balanced share of housework. Policies and cultural norms go hand in hand (Crompton, 2006). Indeed, there is evidence that the relative contribution of fathers to childcare increases with the strength of provisions on leave, childcare and working time; but these policies have not been as successful as hoped. France, for example, has relatively short working hours and generous support for working mothers, but a gender division of domestic work more traditional than in liberal or Scandinavian countries. France also exhibits a higher level of reported work/life conflict. Similar outcomes can spring from very different origins. In liberal regimes, the lack of external support may have compelled men to help their employed wives. In Nordic countries, men are institutionally encouraged to share housework, and they do more housework than men in southern or continental Europe, but not much more than those in liberal countries. In France, parenting policies are generous but they have been designed and promoted to support employment and fertility more than gender equality, with the (unintended) effect of reinforcing norms on the care and domestic work obligations of mothers (Gregory and Windebank, 2000).

\section{Conclusions}

By drawing on existing comparative micro and institutional datasets and offering a synthesis of the main "facts" and arguments provided so far in the literature, this contribution has aimed at giving a systematic overview of differences across European countries in the incidence, types and consequences of labour market interruptions, for both women and men. These differences can be geographically clustered.

Southern countries have experienced a consistent growth in female employment in the last decades. Yet, they haven't reached the Lisbon target (except Cyprus and Portugal). Moreover, these countries continue to exhibit a quite traditional gender division of domestic and care work and an "opt in-opt out" participation pattern. A relatively high share of women, although declining, is "constantly out", that is, it has never started to work in the labour market over their life-courses. Once women have started to work, either they never stop working or, if they do stop, they never re-start. Continuous fulltime participation has always been by far the most typical pattern: movements around motherhood out of the labour market or from full-time to part-time are relatively few. However, these Mediterranean women "constantly in" are a quite "privileged" group: they are mainly highly educated and/or working in the public sector. For them the impact of motherhood on participation, downward mobility and wages is minimal.

Northern countries have one of the highest female employment rates and incidence of continuous careers and one of the highest times for male care. Adjustments around motherhood, both in the form of exits from the labour market and of movements to part-time, are small. Unlike in the Mediterranean countries, the differences according to education level are also small: continuous full-time participation is widespread also among the low educated. So in Nordic countries resumption following leaves seems easier than elsewhere, as well as coming back to the same job. Yet, also in Scandinavian countries children cause the mother to lose human capital accumulation during childbirth periods. Here the wage penalty of motherhoods is minimal because employment interruptions are fewer and shorter. The 
exception in the Nordic cluster is given by the Netherlands, which is indeed a country on the border between the "continental-corporative" model and the "northern-socialdemocratic" model, both in terms of micro behaviours and macro institutional settings. The Netherlands is among the countries where women most adjust their participation around first childbirth, and where they do it mainly moving form fulltime to part-time jobs. Here, in turn, the wage cost of motherhood is higher than in other Nordic countries.

Continental countries have medium-low employment rates and typical discontinuous careers, especially in Germany and Austria. Here indeed a relevant share of women interrupts around childbirth. Among those that do not withdraw from the labour market, the most frequent behaviour is to take long leaves and, after parental leave, to work at reduced hours. Also in France the long parental leave system has been shown to have a negative effect on labour-market participation, especially of mothers of two children, and especially of those who are unskilled, who are less likely to resume work after parental leave. Since women in Continental Europe tend to return to work later than sooner, income losses as well as human capital depreciation are highest than in Scandinavian and Mediterranean countries.

Eastern countries have relatively low employment rates, still below the Lisbon target, although less far than the level observed in Mediterranean countries. In Eastern countries the impact of motherhood on participation, and, in turn, on wages is also high. More precisely, in the Czech Republic, Hungary, and Poland, resuming work to the same extent as before parental leave is quite frequent, but almost equally frequent is exiting from the labour market. Working reduced hours, by contrast, is least common.

Baltic countries have medium-high employment rates and medium-high rates of continuous fulltime careers. Here the negative impact of motherhood is substantial only for the third child. The most frequent behaviour after leave is indeed resume work with the same number of hours, followed by the reduction of working hours.

Finally, Anglo-Saxon countries have reached the Lisbon target of female employment rates (Ireland being very closed). Yet, discontinuous careers around motherhood continue to be the typical pattern. Overall, within Europe the countries where women most adjust their participation around first childbirth are the Netherlands, followed by the UK, then Ireland, Germany, and Belgium. Yet, types of adjustment differ among these countries: as said, in the Netherlands, and to a lesser extent in Ireland, it is movements from full-time to part-time that prevail, whereas in the UK it is movements out of the labour market. In the UK widespread are re-entries on a part-time basis after a labour market interruption. Part-time is also the most frequent pattern after parental leave. Given the weight of interruptions and of part-time work, and also given that human capital accumulation is such an important determinant of wages in Anglo-Saxon labour markets, the wage cost of motherhood is high.

These different geographical groups thus exhibit quite different models of women's labour market interruptions around motherhood. Which models prevails in a particular country, and among whom (all women, mainly the low or the high educated) depends on a number of factors. Policies in support of reconciliation and norms on the appropriate locus of care and the appropriate gender roles are crucial. More precisely, policies that "defamilialise" caring responsibilities and child costs, especially childcare services and maternal, parental and paternity leave policies are primordial. The effect of these measures on women's employment patterns and on the wage cost of motherhood depends on how they are individually designed and how they interact with each as a package. The effect also depends on how they promote gender equality within the family, that is, whether and how they encourage men to share time for domestic and care work. The geographical groups broadly exhibit different types and orientations of reconciliation policies.

Southern Countries record one the lowest public spending for families with children. Less than $6 \%$ of children under 3 are looked after in a public crèche, and availability of flexible working time arrangements is small. Maternity leaves are generous, both in duration and in wage replacement rates. Parental leaves are individual-based, quite long and flexible in their use, and in Italy and Portugal are paid at around $30 \%$ of previous wage. Greece, Spain and Portugal have also introduced short paternity leave, paid at $100 \%$. But cultural support for maternal employment is among the lowest in Europe, likewise for men's share of domestic and care responsibilities. 
Northern Countries have among the highest percentages of public spending and, one of the highest shares in services versus family benefits in cash. Level of coverage of public childcare services for the under three is at a maximum. Maternity and parental leave are not so long, but they are individualbased, flexible in their use, and cover $70 \%$ to $100 \%$ of previous wages. Paternity leave is the longest and best paid in Europe. Northern men on average devote more time to care and domestic work, and the gap with their female partners is less pronounced then elsewhere.

Continental countries record a high percentage of public spending but the weight is more towards family benefits in cash than towards services. These cover less than $10 \%$ of children under 3 in Luxembourg, Austria and Germany, about 35\% in France and Belgium. The former also do not offer paternity leave, while the parental leave in the latter is family-based and among the longest in Europe.

Eastern countries record medium level of public spending and is more orientated towards cash benefits than services. Eastern countries combine low provision of formal childcare arrangements with family income transfers, and long maternity leave with no paternity leave. They have the longest parental leave within the EU, with family-based entitlements, and among the lowest replacement rates.

Baltic countries record, together with Mediterranean countries, show the lowest public spending for families. Formal childcare arrangements are few. Compared to Eastern countries, maternity leave is shorter combined with a few days of paternity leave. Parental leave is similarly long and family-based.

Finally, Anglo-Saxon countries record quite high levels of public spending, but in cash rather than services. Indeed, within Europe, the provision of public childcare arrangements is one of the lowest, like the length of parental leave and the replacement rates of both maternity and parental leave.

There seems to be a correspondence between levels and type of spending and levels and type of women's labour-market participation. Countries with higher incidences of continuous careers are those that spend more on families and, within such investment, they are those that spend more on childcare services than on cash transfers. In these "successful" countries leaves are not the longest. Rather, they are more shared with men, better paid, and more combined with other measure of reconciliation, namely with out-of-home childcare services and with working time flexibility. Everywhere the effect on occupational mobility and on future participation is much stronger when women take long leaves or withdraw from the labour market for some years.

For policy makers the optimal length of leaves is an important issue, that is the maximum length that does not lead to deteriorating prospects of employment, working conditions or career after resuming work. Yet, from the literature reviewed in this paper one can see that the answer is not straightforward. The case of Germany shows that a generous system of maternity and parental leaves, not paralleled with a generous provision of childcare services, make full-time motherhood relatively cheap compared to combining work and family, with a negative impact on subsequent participation, job position and wages. The case of Sweden shows that more than single measures crucial are packages of policies that combine all three pillars of income, services and time. Crucial is also the extent to which they encourage and "normalise" gender equality within families, that is, men's participation in domestic and care work. Since not all care can be commodified, more attention should be paid to the issue of distribution of care not only between market, state and family but also between men and women (Crompton 2006; Lewis, 2006; Gornick and Meyers 2003). In order to enable both men and women to choose to engage in paid or unpaid work policies have to make a logical shift: if one follows Sen (1992) in adopting a multidimensional concept of welfare, not only money and economic life, but also time, care and political, social and family life, become important factors. Defining the goals of the welfare state in terms of well-being, rather than only work and wages, means that policies should not focus only on the work/welfare relationship and on the support to mother's participation in the labour market, they should also address the distribution of time and the support for men's participation in the family.

\section{References}

AFSA C. (1999). "L'allocation parentale d'education: entre politique familiale et politique de l'emploi", Donnees Sociales. 
AISENBREY S., EVERTSSON M. and GRUNOW D. (2008). "Is There a Career Penalty for Mothers' Time Out? A Comparison of Germany, Sweden and the United States", Social Forces, Vol. 88, N. 2, December, pp. 573-605.

AKGUNDUZ, Y. E. and PLANTENGA, J. (2011). Labour Market Effects of Parental Leave: A European perspective, Discussion Paper 11-09, Tjalling C Koopmans Research Institute (Utrecht University)

ALBRECHT, J.W.; EDIN, P.-A.; SUNDSTROM, M. AND VROMAN, S.B. (1999). Career Interruptions and Subsequent Earnings: A Reexamination Using Swedish Data, Journal of Human Resources 34(2), 294-311.

BEBLO M. and WOLF E. (2002). "Wage Penalties for Career Interruptions. An Empirical Analysis for West Germany", Discussion Paper N. 02-45, ZEW (Centre for European Economic Research).

BETTIO F. and PLANTENGA J. (2004). "Comparing Care Regimes in Europe", Feminist Economics 10(1): 85-113.

BETTIO F., PLANTENGA J and SMITH, M. (EDS) (2013), Gender and the European Labour Market, London : Routledge

BISON I., PISATI M. and SCHIZZEROTTO A. (1996). "Disuguaglianze di Genere e Storie Lavorative" In S. Piccone Stella and C. Saraceno (eds) Genere: La Costruzione Sociale del Femminile e Maschile. Bologna: Il Mulino.

BULIGESCU B., DE CROMBRUGGHE D., MENTESOĞLU G., and MONTIZAAN R. (2008). "Panel estimates of the wage penalty for maternal leave", Oxford Economic Papers 61 (2009), 35-55.

CROMPTON R. (2006). Employment and the Family: the Reconfiguration of Work and Family Life in Contemporary Societies, Cambridge: Cambridge University Press.

DE HENAU J., MEULDERS D. and O'DORCHAI S. (2007). "Parents' Care and Career. Comparing Parental Leave Policies across EU-15", In: Del Boca, D. and C. Wetzels (eds.) Social Policies, Labour Markets and Motherhood: a Comparative Analysis of European Countries, Cambridge, Cambridge University Press.

DEL BOCA D. and PASQUA S. (2005a). "Social Policies and Employment of Married Women in Europe," CHILD Working Papers wp19_05, CHILD - Centre for Household, Income, Labour and Demographic economics

DEL BOCA D. and PASQUA S. (2005b). "Labour Supply and Fertility in Europe and the U.S.", in T. Boeri, Del Boca D. and Pissarides C. (eds.) Women at Work. An Economic Perspective, Oxford University Press.

DEL BOCA D. and WETZELS C. (2007) eds. Social Policies, Labour Markets and Motherbood: a Comparative Analysis of European Countries. Cambridge University Press.

EIGE (2011). "Review of the Implementation of the Beijing Platform for Action in the area F: Women and the Economy, Reconciliation of Work and Family Life as a Condition of Equal Participation in the Labour Market." Report financed by and prepared for the use of EIGE (European Institute for Gender Equality), Luxembourg.

EJRNAES M. and KUNZE A. (2004). "Wage Dips and Drops around First Birth", IZA Discussion Papers 1011, Institute for the Study of Labor (IZA).

ESPING-ANDERSEN G. (2009). The Incomplete Revolution: Adapting to Women's New Roles Cambridge: Policy Press.

EUROPEAN CHILDCARE NETWORK. (1994). "Leave Arrangements for Workers With Children: A Review of Leave Arrangements in the Member States of the European Community and Austria, Finland, Norway and Sweden", Report Prepared for the Equal Opportunities Unit (DGV). Brussels: European Commission.

EUROFOUND (2006). Working time options over the life course: new work patterns and company strategies. Luxembourg: European Foundation for the Improvement of Living and Working Conditions.

EUROSTAT. (2009). Reconciliation of Work, Private and Family Life in the European Union, Luxembourg: European Commission. 
FAGNANI J. (1996). "Family Policies and Working Mothers: a Comparison of France and West Germany" In Garcia-Ramon M. D. M. J. (eds) Women of the European Union. The Politics of Work and Daily-Life, London: Routledge.

FINN, M. and HENWOOD, K. (2009). "Exploring masculinities within men's identificatory imaginings of first-time fatherhood", British Journal of Social Psychology, 48, 547-562.

FRANCAVILLA F., GIANNELLI G., GROTKOWSKA G., PICCOLI L. and SOCHA M. (2009). Women and unpaid family care work in the EU. European Parliament. Directorate-General for Internal Policies, Policy Department Citizens' Rights and Constitutional Affairs

FRASER N. (1994). "After the Family Wage: Gender Equity and the Welfare State" Political Theory 22: 591-618.

GANGL M. and ZIEFLE A. (2009). "Motherhood, Labor Force Behavior, and Women's Careers: An Empirical Assessment of the Wage Penalty for Motherhood in Britain, Germany, and the United States", Demography, May; 46(2): 341-369.

GEIST C. (2005). "The Welfare State and the Home: Regime Difference in the Domestic Division of Labour". European Sociological Review. 21:23-41.

GORNICK J. C. and MEYERS M. K. (2003). Families That Work: Policies for Reconciling Parenthood and Employment, New York: Russell Sage Foundation.

GORNICK J., MEYERS M. K., and ROSS K. (1997). "Supporting the Employment of Mothers: Policy Variation Across Fourteen Welfare States", Journal of European Social Policy 1(45-70).

GREGG, P and TOMINEY, E (2003). "The wage scar from youth unemployment," CMPO Working Paper 04/097

GREGG, P and TOMINEY, E (2005). "The wage scar from male youth unemployment," Labour Economics, Elsevier, vol. 12(4), pages 487-509.

GREGORY A. and WINDEBANK J. 2000). Women's Work in Britain and France: Practice, Theory and Policy, London: Macmillan.

GUSTAFSSON S. (1994). "Childcare and Types of Welfare States" In D. Sainsbury Gendering Welfare States, London: Sage.

HOLTER, Ø. G. (2007). 'Men's Work and Family Reconciliation in Europe'. Men and Masculinities 9/4: 425-456.

JAUMOTTE, F. (2003). Female Labour Force Participation: Past Trends and Main Determinants in OECD Countries. OECD Economics Department Working Papers.

KARU M. and PALL K. (2009). "Estonia: from Soviet Union to half way to the Nordic Countries", in Kamerman S. B. and Moss P. (eds) The politics of parental leave policies: Children, parenting, gender and the labour market, pp. 69-85 (Bristol: The Policy Press).

KENJOH E. (2005). "New mothers' employment and public policy in the Uk, Germany, The Netherlands, Sweden and Japan". Labour 19 (Special issue) 5-49.

KLERMAN J. A. and LEIBOWITZ A. (1997). "Labor Supply Effects of State Maternity Leave Legislation", in Blau F. D. and Ehrenberg R. G. (eds) Gender and Family Issues in the Workplace, Russell Sage Foundation, New York, 65-91.

LEITNER S. (2003). "Varieties of Familialism: The Caring Function of the Family in. Comparative Perspective" European Societies, 5: 353-75.

LEWIS J (2003). "Developing Early Years Childcare in England, 1997-2002: The Choices for (Working Mothers" Social Policy and Administration, Vol. 37, 2003, p.219-238

LEWIS J. (2006). "Employment and care: the policy problem, gender equality and the issue of choice". Journal of comparative policy analysis. Routledge, 8 (2): 103-114.

MCLAUGHLIN E. and GLENDINNING C. (1994). "Paying for care in Europe: is there a feminist approach?", in L. Hantrais and S. Morgan (eds) Family Policy and the Welfare of Women. Cross-National Research Papers, $3^{\text {rd }}$ series, 3 (European Research Centre, University of Loughborough).

MENCARINI, L and SOLERA, C. (2011). "Percorsi verso la vita adulta tra lavoro e famiglia: differenze per genere, istruzione e coorte”. In: Sartor N., Schizzerotto A. e Trivellato U. (a cura di) Generazioni diseguali.Le condizioni di vita dei giovani di ieri e di oggi: un confronto. Bologna: Il Mulino: pp 175-209. 
MISRA J., BUDIG M. J. and MOLLER S. (2007). "Reconciliation policies and the effects of motherhood on employment, earnings and poverty", Journal of Comparative Policy Analysis: Research and Practice, 9:2, 135-155.

NALDINI, M. and SARACENO, C. (2011). Conciliare famiglia e lavoro. Vecchi e nuovi patti tra sessi e generazioni, Il Mulino, Bologna

PIKET'TY T. (2003). "L'impact de l'allocation parentale d'education sur l'activite feminine et la fecondite, 1982-2002", Working paper CEPREMAP, n²003/9.

PLANTENGA J. and REMERY C. (2009a). Flexible working time arrangements and gender Equality. A comparative review of thirty European countries. EU Expert Group on Gender and Employment (EGGE).

PLANTENGA J. and REMERY C. (2009b). The provision of childcare services. A comparative review of 30 European countries. European Commission Directorate-General for Employment, Social Affairs and Equal opportunities.

PRONZATO C. (2007). "Return to Work after Childbirth: does Parental Leave matters in Europe?", ISER Working Paper 2007-30. Institute for Social and Economic Research.

RAY, R., GORNICK, J. and SCHMITT J. (2010). "Who cares? assessing generosity and gender equality in parental leave policy designs in 21 countries", Journal of European Social Policy, 20 (3), 196-216.

REICH, N. (2011). "Mothers' Employment and Wages in Europe: Does Parental Leave Matter?", Working Paper, presented at the IAFFE International Conference in Hangzhou, China, 2011.

RUHM, C. J. (1998). The Economic Consequences of Parental Leave Mandates: Lessons From Europe, Quarterly Journal of Economics, vol. 113, no. 1, 285-317.

SARACENO, C (2000) "Gendered Policies: family obligations and social policies in Europe", in T. P. Boje e A, Leira, Gender, Welfare State and the Market, Routledge, London, 2000, pp.135-56

SARACENO, C. and KECK, W. (2010): Can We Identify Intergenerational Policy Regimes in Europe? European Societies, 12 (5), pp. 675 - 696

SCHIZZEROTTO, A., I. BISON, and A. ZOPPE. (1995). "Disparità di genere nella partecipazione al mondo del Lavoro e nella durata delle carriere", Polis 9(1), 91-112.

SCOTT, J., DEX, S. and JOSHI, H. (2009). Women and Employment: Changing Lives and New Challenges, London: Edward Elgar.

SEN, A. (1992). Inequality Re-examined, Oxford: Oxford University Press.

SMITH, A. (2004) "Who Cares? Fathers and the Time They Spend Looking After Children", Working Paper Number 2004-05, Department of Sociology, University of Oxford, July 2004.

SMITH A. and WILLIAMS D.R. (2007). "Father-friendly Legislation and Paternal Time Across Western Europe", Journal of Comparative Policy Analysis, Spring.

SMITH KOSLOWSKI, A. (2011). "Working Fathers in Europe: Earning and Caring", European Sociological Review, 27 (2), 230-245.

SOLERA C. (2009). Women in and out paid work. Changes across Generation in Italy and Britain, Policy Press.

SOLERA C. and BETTIO F. (2013). "Women's Continuous Careers in Italy: The Education and Public Sector Divide.", Population Review 52 (1) (this is part of a special collection edited by Teresa Martin-Garcia)

SOLERA C. and NEGRI N. (2008). "Conciliazione famiglia-lavoro: strategia ex-ante o ex-post? Una analisi su coppie vulnerabili nel Canavese", in Rinaldi W. (ed) Giustizia e Povertà. Universalismo, cittadinanza, capabilities, Bologna: il Mulino.

STIER H. and LEWIN-EPSTEIN N. (2001). "Welfare Regimes, Family-Supportive Policies, and Women's Employment Along the Life-Course." American Journal of Sociology 106(6):1731-60.

UUNK W., KALMIJN M. and MUFFELS R. (2005). "The Impact of Young Children on Women's Labour Supply: A reassessment of Institutional Effects in Europe”. Acta sociologica vol. 48(1): 41-62

WALDFOGEL J., HIGUCHI Y. and ABE M. (1999), "Family leave policies and women's retention after childbirth: Evidence from the United States, Britain, and Japan", Journal of Population Economics, 12: 523-545. 